\title{
Assessment of Efficiency of Capital Investment Project Implementation of Resource-saving Technology for the Real Sector of the Economy in Tatarstan Republic
}

\author{
Asiya Sh. Khasanova \\ Gulnara M. Kvon \\ Kazan National Research Technical University named after A.N.Tupolev - KAl (KNRTU-KAl), 420015, Kazan, Russia \\ Email: sung2002@mail.ru \\ Nailya M. Yakupova \\ Kazan Federal University, 420008, Kazan, Russia \\ Farid F. Khamidullin \\ University of Management «TISBI», 420012, Kazan, Russia \\ Ekaterina Y. Samysheva
}

Kazan National Research Technical University named after A.N.Tupolev - KAl (KNRTU-KAI), 420015, Kazan, Russia

\section{Doi:10.5901/mjss.2015.v6n2s3p155}

\section{Abstract}

\begin{abstract}
The timeliness of the problem under study stems from the fact that realization of resource-saving technologies requires in its turn the implementation of innovative technologies in different branches of industry of Tatarstan Republic. The object of an article includes the statement of need of high-impact projects implementation in the area of field facilities construction by making use of pipes with cathodic protection, which is verified by accounting results of economic efficiency. The principle method of investigation of this problem is a method of assessment of efficiency of capital investment project with the use of discounted methods of calculation that will allow take into account asynchronical cash inflow and outflow of implementing project. The results of the investigation that is focused on assessment of efficiency of plant establishment for the production of resource-saving technologies in the oil industry confirm practicability of such project investment. The plan that allows realizing the pipes with cathodic protection guarantee investors and project parties' acceptable performance measurements. Information in article could be useful in realization of similar projects; they include the methodological tools for project evaluation and accounting results that confirm the conclusions of the authors.
\end{abstract}

Keywords: innovation technologies, efficient use of resources, investments, efficiency of investment project

\section{Introduction}

\subsection{The Timeliness of the Problem}

The goal of investment in advanced society is economical advance, presence of which allow increase the cost of national production investment capital (Gukova, 2006). Implementation of innovative products that meet the requirements of the region form investment demands.

It is necessary to notice that space planning of oil fields require usage of large amount of oil equipment. Crude-oil production performed with the use of reservoir pressure maintenance system (RPMS) could be realized with formidable pipeline basis for wastewater injection, reservoir services, pumps and other at hand. In consideration of significance and expanse of pipeline transportation system in republic, which used in RT oil companies and it is susceptibility to corrosion because of corrosive wastewaters injection, flowline with cathodic protection has particular actuality. In republic, which is the leader among other regions in field facilities installation with the use of anti-corrosive measures of various kinds, nonetheless remains a need in further development and use of pipes with cathodic protection in oil facilities. 


\subsection{Explore Importance of the Problem}

Modern stage of development of fuel and energy complex in Russia and its regions characterized by high amortization of fixed capital stock (Kondratiev, 2005).

Author's experience in oil industry suggests that for the last decades operating life of steel pipes decreased almost in all areas of their application. This based, from one side, on sharp decrease of metal's corrosion resistance and, from the other side, on an increase of environment's corrosive activity wherein pipes are operated. Flowlines that do not have internal coat, in which aggressive substances being transported, has operating life from one month to two years that does not allow them to "serve" it's serviceable life. For the last decades has been noted the decrease of operating life in almost all spheres of their application that is based, from one side, on sharp decrease of metal's corrosion resistance and, from the other side, on an increase of environment's corrosive activity wherein pipes are operated. This results in substantial casualties from underamortization of these oil-field facilities, which lead to substantial losses in enterprises that implement pipes without cathodic protection.

Within this framework, we consider relevant the implementation of different anti-corrosive internal and external coats in steel pipes and flowlines constituent elements establishing for that purpose plant (production facility) for the production of pipes.

\subsection{Subject Matter of Capital Investment Project.}

Capital investment project under discussion suggest the establishment of new plant for the application of internal and external anti-corrosive coat in steel pipes.

Established production facility suggests the organization of innovative manufacture for the application of internal and external anti-corrosive coat in steel pipes for the purpose of optimizing the pipe line service life, for the losses reduction due to worn-out state of flow lines in Russia and neighboring countries and also for the purpose of improvement of the effectiveness of newly introduced pipe lines usage. Despite the fact that large number of enterprises that issue equipment with anti-corrosive protection has been established in Tatarstan, build up production use unique German and Italian equipment for the application of internal and external coat in releasing pipes, which has no analogues in Russian Federation.

Making pipes with advanced reliability will allow providing both environmental integrity and safety of the flowlines itself, which work in aggressive environment, therefore increase its service life. Factors that determine possibility and necessity of realization of project on production facility for steel pipes insulating coating establishment are:

- the gain (accession) in production of pipes with anti-corrosive protection;

- objectively conditional high deprecation of pipelines and necessity of its replacement including also those pipelines that were built in republic in the 90s;

- the absence of similar manufactures in the territory of the Russia and neighboring countries;

- $\quad$ more efficient use of available pipelines in the territory of the Russian Federation;

- service life of steel pipes with cathodic protection exceed service life of pipes without protection fivefold and more;

- $\quad$ using pipes with internal polymeric coating not only provides effective protection from corrosion, but allow to increase flow capacity (on 5-15\% and more), and also significantly reduce the amount of sedimentation in its internal surface;

- flowlines with internal polymeric coating need cleanout less often and retain original capacity during long period of operation.

\subsection{Status of a Problem}

Aspects of corrosion prevention of pipes are under consideration in RT from the beginning of 1990s. Projects implementation on adaption of pipes with corrosion prevention gave an option in republic in due time of escaping environmental catastrophe. Works on this subject published in proceedings of such scientists and practitioners in Tatarstan as Zagirov M.M., Takhautdinov Sh.F. (Takhautdinov, 1998), (Zagirov, 1998). Theoretical aspects of justification of investment projects efficiency presented in proceedings of Behrens (Behrens, 1995), Lipsitz (Lipsitz, 2011) and others. Economic aspects of expediency evaluation of resource - saving manufactures development published in proceedings of Khasanova A.Sh. (Khasanova, 2014), Kvon G.M. (Kvon, 2005, 2009, 2014). 


\section{Materials and Methods}

\subsection{Research Objectives.}

In the course of research following problems were determined:

1) assortment and substantiation of benchmark data for the calculation of the project;

2) carrying-out of an analysis of similar manufactures implementation;

3) justification of methodological framework for the cost-effectiveness analysis of a project;

4) carrying out a cost-effectiveness analysis of investment project of investigational and observational group in the process of tourism activities;

5) input-output analysis of assessment of efficiency of resource saving manufacture establishment.

\subsection{Theoretic and Empiric Research Methods.}

In the course of work, different methods used:

- methods of investment analysis, which based on discounting conception,

- quantitative and qualitative methods of risk assessment,

- expert evaluation method,

- analysis and synthesis method,

- statistical methods.

\subsection{Estimation Criterions}

During assessment of efficiency of capital investment project that focused on increased investment appeal of a company there are certain estimation criterions in terms of which managerial decisions on accepting (or denial) of project are made. During assessment of projects according to the Methodological Recommendations on Estimation of Project's Efficiency (Methodological Recommendations, 2010) and Guidance on Investment Assessment of Efficiency (Behrens, 1995) could be used two groups of methods: simple and complex.

To the simple methods that do not use discounting conception could be related simple pay-back time and simple rate of profit. These activities are very convenient in the calculation; however they do not take into account asynchronicity of money flows and runoffs (Askinadze, 2010).

To the complex methods that take into account irregularity of moneys received and runoffs, based on discounting conception (with an allowance for risk and uncertainties) relate:

- NPV - net present value;

- PI - profitability index;

- $\quad$ IRR - internal rate of return;

- DPP - discounted payback period or payback period. Table 1.

Calculation and methodological aspects of analysis of general indicators of return on investments presented in

Table 1. Settlement and Methodological Aspects of Analysis of Generalized Index of Effectiveness of Long-range Investments

\begin{tabular}{|l|l|l|}
\hline Indicator name & Calculation Methodology & Substantiation \\
\hline $\begin{array}{l}\text { 1. Net present value (NPV) - difference between } \\
\text { aggregate amount of discounted cash flow for the } \\
\text { whole period of IP realization and primary amount } \\
\text { of investment expenditures }\end{array}$ & $\begin{array}{l}N P V=P V-l o \\
\text { or }\end{array}$ & $\begin{array}{l}\text { - if NPV }>0, \text { project will be accepted, } \\
\text { if NPV <0, project will be discarded, } \\
\text { - if resented projects have alternative than } \\
\text { project with highest NPV should be } \\
\text { accepted }\end{array}$ \\
\hline $\begin{array}{l}\text { 2. Internal rate of return (IRR)- minimum value } \\
\text { of profitability wherein investments will be } \\
\text { compensated in planned period of project's } \\
\text { implementation }\end{array}$ & This index is calculated by the following equation: & $\begin{array}{l}\text { If internal revenue rate exceed the price of } \\
\text { vested capital, company should accept the } \\
\text { project otherwise it should be discarded. }\end{array}$ \\
\hline $\begin{array}{l}\text { 3. Pay-back period (PP) determine space of time } \\
\text { which is needed for refunding of investment } \\
\text { expenditures from net cash flow. }\end{array}$ & $\begin{array}{l}\text { If the amount of cash flow is constant in every period } \\
\text { of investment project realization, than calculation } \\
\text { formula of PB could be presented as follows: }\end{array}$ & $\begin{array}{l}\text { - projects with payback period less than } \\
\text { standard laps of time specified by investors } \\
\text { (or business entity itself) are accepted, with } \\
\text { bigger payback period are discarded; }\end{array}$ \\
\hline
\end{tabular}




\begin{tabular}{|l|l|l|}
\hline & $\begin{array}{l}P P=\frac{I_{0}}{C F} \\
\text { If CF nonequivalent against each other in different } \\
\text { periods of time than pay-back period should be } \\
\text { determined from the formula: } \\
\left(\begin{array}{l}\left(I_{0}-\left\lfloor C F_{1}+C F_{2}+\ldots+C F_{j}\right\rfloor\right) \\
C=\frac{C F_{j+1}}{2}\end{array}\right.\end{array}$ & $\begin{array}{l}\text { - from several mutually exclusive projects } \\
\text { should be accepted project with lesser } \\
\text { payback period }\end{array}$ \\
\hline $\begin{array}{l}\text { 4. Profitability index (PI) is equal to the present } \\
\text { value of cash flow divided on the amount of } \\
\text { investment expenditures }\end{array}$ & $P I=\frac{P V}{I_{0}}$ & $\begin{array}{l}\text { For as long as PI greater than unity, project } \\
\text { could be accepted for the implementation }\end{array}$ \\
\hline
\end{tabular}

In compilation of a table were used following notational conventions:

PV - present value of cash flows: $P V=\sum_{t=1}^{n} \frac{C F_{t}}{(1+r)^{t}}$

Io - initial investment costs;

CFt - cash flow from an investment project in year $t$;

$\mathrm{n}$ - number of years during which the investment project is realized;

$r$ - discount rate of the project.

Particular importance has definition of discount rate (Kiseleva, 2013). From a mathematical standpoint discount rate is a rate per cent, which is used for reevaluation of future income flow into a single value of present (today's) cost. This rate per cent is the basis for determination of market capitalization. In economic terms, discount rate appears as a rate of return for invested capital required by investors in investment projects with a comparable level of risk. Or this is a required rate of return on available alternative choice of investment with a comparable level of risk by the date of estimating (Yacupova, 2010).

Discount rate, or capital dotation costs, should be calculated in compliance with three factors:

1. The fact that many enterprises has different sources of raised capital that require different levels of compensation.

2. Necessity of taking into account for investors the value of money in time.

3. Risk factors or degree of possibility of getting expected income in future.

Methods for determining of cash flow discount rate are different but the most commonly encountered from them are:

- methodology for ownership capital - capital asset pricing model (CAPM) and build-up method;

- methodology for invested capital - weighted average cost capital model (WACC), where as balance appear parts of borrowed and internal resources within capital.

Assessment of efficiency of project by means of abovementioned factors allow project's organizer to make right investment decision.

\section{Results}

During estimation of investment expenditures was discovered that realization of this capital investment project on the establishment of plant for the application of coating in steel pipes require following investment expenditures (in \$ thousands)

overall: 11530, including:

Manufacturing equipment including installation $\quad 9779$

Pre-production expenses $\quad 750$

Increment of operating capital 1002

The amount of capital assets is based on purchase costs of production equipment (main and secondary), license, transportations, installation costs, construction of roads and communication lines, product certification and other.

It is necessary to point out that project's organizer does not have the whole amount of money, it come out at \$ 6572 thous., which is $57 \%$ of the cost of entire project. Necessary amount of attraction of credit resources to be $\$ 4958$ thous., which is $43 \%$ of the cost of entire business project on factory establishment.

To determine indexes of efficiency of capital investment project "Establishment of the Plant for the Application of Anti-corrosive Coating in Steel Pipes" we must perform settlements of reviewed indexes PI, NPV, DPP and IRR. 
Net present value or NPV is defined in such a manner: at the first stage we should calculate net cash flow.Next we should calculate cash flow exclusively accumulative (positive accumulative cash flow could be evidenced). Up to that moment this index was negative. Afterwards net cash flow should be discounted.

Next index of efficiency of capital investment project is discounted profitability index (payability) - PI

This index demonstrate how profitable is capital investment project or how much profit could be gained from realizing the project on 1 ruble of invested in this project assets.

Index that distinguish cumulative rate of return of invested assets in project, which is generated for specific project, is internal rate of return (IRR). More fast and accurate IRR could be determined with the help of financial calculator or computer using EXCEL.

The last index of efficiency of capital investment project "Establishment of the Plant for the Application of Anticorrosive Coating in Steel Pipes" is payback period.

The results of calculation of the project, made with due account for UNIDO procedure (Guidance, 1995), and Methodological Recommendations (Methodological Recommendations, 2010):

Net present value (NPV), in \$ thousands - 24303

Internal rate of return (IRR), \% - 45,6\%

Простой срок окупаемости проект (PP), year - 3,4

Profitability index (PI), index. $\quad-3,1$

Detailed index's calculation is demonstrated in Table 2.

Table 2. Results of an Investment Project Realization

(in \$ thousands)

\begin{tabular}{|c|c|c|c|c|c|c|c|c|}
\hline \multirow{2}{*}{ Indices } & \multicolumn{7}{|c|}{ Years of the project (accounting period) } & \multirow{2}{*}{ In total } \\
\hline & 1 & 2 & 3 & 4 & 5 & 6 & 7 & \\
\hline Investment activity & 11530 & & & & & & & 11530,2 \\
\hline Manufacturing equipment including installation & 9779 & & & & & & & \\
\hline Pre-production expenses & 750 & & & & & & & \\
\hline Increment of operating capital & 1002 & & & & & & & \\
\hline \multicolumn{9}{|l|}{ Operating activity } \\
\hline Operating income & 0 & 0 & 49144 & 49144 & 49144 & 49144 & 49144 & 245721 \\
\hline Operating costs & 179 & 224 & 36478 & 36478 & 36478 & 36478 & 36478 & 182791 \\
\hline Amortization & 0 & 0 & 556 & 556 & 556 & 556 & 556 & 2779 \\
\hline Taxes and interest on credit & 1,17 & 301 & 1011 & 940 & 869 & 797 & 726 & 4646 \\
\hline The balance sheet profit as restated & -180 & -526 & 11100 & 11171 & 11242 & 11313 & 11384 & 55505 \\
\hline Adjustment of taxable profit & 0 & -180 & -706 & 0 & 0 & 0 & 0 & -886 \\
\hline Taxable profit & 0 & 0 & 10394 & 11171 & 11242 & 11313 & 11384 & 55505 \\
\hline Tax on profits & 0 & 0 & 2079 & 2234 & 2248 & 2263 & 2277 & 11101 \\
\hline Interest on loans is not included in the cost & 0 & 300 & 0 & 0 & 0 & 0 & 0 & 300 \\
\hline Net income (profit) & -180 & -226 & 8315 & 8937 & 8994 & 9051 & 9108 & 43999 \\
\hline \multirow[t]{2}{*}{ Net cash flow } & -180 & -226 & 8871 & 9493 & 9549 & 9606 & 9663 & 46777 \\
\hline & \multicolumn{7}{|c|}{ Calculation of project performance indicators } & \\
\hline Investment activity outcome (result) & $-11530,2$ & & & & & & & $-11530,2$ \\
\hline Operating activity outcome (result) & -180 & -226 & 8871 & 9493 & 9549 & 9606 & 9663 & 46777 \\
\hline Real money flow & -11710 & -226 & 8871 & 9493 & 9549 & 9606 & 9663 & 35247 \\
\hline The same, but on an accrual basis & -11710 & -11936 & -3065 & 6428 & 15977 & 25584 & 35247 & \\
\hline \multirow[t]{2}{*}{ Discounted cash flows of real money } & -11710 & -10754 & -2489 & 4699 & 10529 & 15171 & 18857 & 24303 \\
\hline & \multicolumn{7}{|c|}{ Performance indicators project } & \\
\hline Net present value (NPV), (in \$ thousands & & & & & & & & 24303 \\
\hline Internal rate of return (IRR), \% & & & & & & & & $45,6 \%$ \\
\hline Payback period (PP), year & & & & & & & & 3,4 \\
\hline Profitability index (PI), index & & & & & & & & 3,1 \\
\hline
\end{tabular}

To further define the practicability of realization of capital investment project we need to determine risks of a project that will help to make final conclusions on extent of its effectiveness (Abramov, 2012), Khamidullin (2012).

In the frame of investigated capital investment project made the break-even analysis of manufacture, namely was calculated earnings threshold. 
Calculation of breakeven point (earnings threshold) allows seeing to what extent could come down earnings. In this point enterprise do not have earnings (profit is equal to 0), but also do not have losses. Calculation was made on the basis of marginal analysis. Constant decrease tendency of considered project performance figure admitted as positive. According to the performed calculations margin of safety of actual earnings of the project is $75,5 \%$ in the third year of production, $76,1 \%$ - $4^{\text {th }}$ year, $76,6 \%$ - $5^{\text {th }}$ year and $77 \%$ - in the $7^{\text {th }}$ year of project's realization. Increase of safety factor over the period under review recognized as a positive point.

Calculation of an earnings threshold presented in Table 3.

Table 3. Indexes of the Liminal Operating Proficiency of the Production

(in $\$$ thousands)

\begin{tabular}{|l|c|c|c|c|c|c|c|}
\hline \multirow{2}{*}{ Indices } & \multicolumn{7}{|c|}{ Years of the project (accounting period) } \\
\cline { 2 - 9 } & 1 & 2 & 3 & 4 & 5 & 6 & 7 \\
\hline Variable costs & 61 & 107 & 36257 & 36413 & 36427 & 36441 & 36455 \\
\hline Fixed costs & 117 & 417 & 3155 & 3095 & 3035 & 2975 & 2915 \\
\hline Marginal profit & & & 12887 & 12732 & 12717 & 12703 & 12689 \\
\hline Breakeven point (earnings threshold) & & & 12032 & 11947 & 11728 & 11509 & 11290 \\
\hline
\end{tabular}

\section{Discussion}

The valid point is the question of promotion of plant's production for the purpose of realization of its investment strategy (Lakhmetkina, 2012).

In the matters of the beginning of capital investment, project realization main efforts of business in marketing policy must be focused on optimization of transportation for different kinds of customers. It is necessary to describe and to prove to the potential customers the ability to provide effective and minimal at the price delivery of the goods planned to be produced, to facilitate turn out products with necessary certificates and to achieve during production quality of production corresponding to these documents. In other words, price, assortment and satisfaction of market's wants of the goods planned to be produced mast guarantee customers economic efficiency of cooperation with the factory. As noted above, production is innovative and in such planned assortment, no one has similar production. Company's strategy for the next 5-10 years is marketing development in Russia and orientation on neighboring countries and beyond. Marketing strategy of capital investment project realization is presented on pic.1.
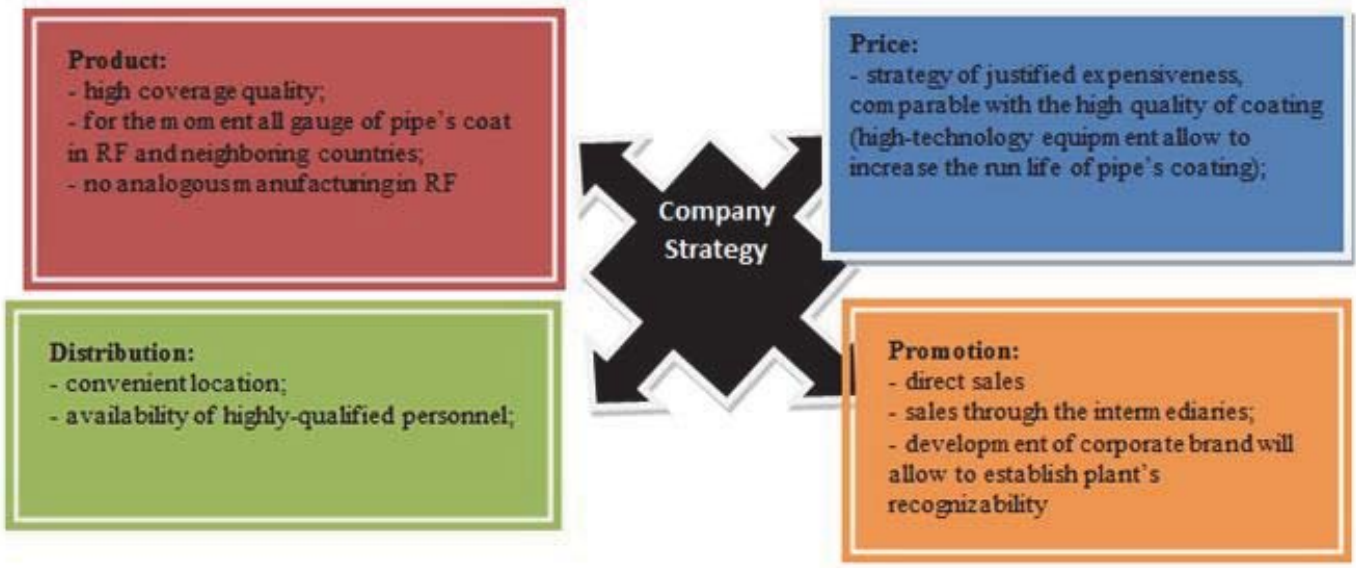

Pic. 1. Competitive Marketing Strategy of a Project of the Organization of Innovative Manufacture for the Application of Anti-corrosive Coat

The main factors of competitiveness of capital investment project are:

1) Procured equipment allow to increase output of products with minimal financial investments up to two times, at that the quality of issued pipe remained unchained.

2) Estimated innovative manufacture always offer the possibility of bringing in additional funding for geographical expansion and establishment of new analogous manufactures in other regions of the country and neighboring 
countries.

3) Build up business with high-technology equipment at hand have an opportunity of nomenclature enlargement of coating types, specifically yielding of another two types of pipes: PCOT (polymer-coated oilwell tubing (internal)) and PCDP (polymer-coated drill-pipe (internal)). They are used in oil and gas extraction and well site construction.

4) On the basis of new established manufacture it is possible also to create a new enterprise on condition monitoring and further pipeline repair, this will allow to carry out diversification of business activity (was not considered in this project).

5) Prognosticate the development of distribution area in all regions of Russia and neighboring countries, such as Kazakhstan, Uzbekistan, Republic of Belarus, Ukraine and other.

\section{Conclusion}

Consequently, considering capital investment project assume the establishment of new plant for the application of internal and external anti-corrosive coat in steel pipes. In the article were studied calculation data of economic efficiency of this investment project.

Calculation confirm the practicability of investments, capital investment project on the ground of calculated indexes of a project was recognized as effective, could return a profit in future and meet investor's expectations;

- produced breakeven results allow to confirm: project on manufacture establishment is resistant to the changes (falldown) of sale results, as evidenced by margin of safety of $75-77 \%$ in 7 years.

\section{References}

Abramov, A.A, Antonov I.V (2012). Risk assessment of the investment project on the basis of adjusted cash flows, The economic analysis: theory and practice, 8 (263) 9.12.

Askinadze, V.M Maksimov, V.F, Petrov, V.S (2010). Investment case: a textbook. M .: Market DS 512.

Berens, V, Havranek P.M (1995). Guidelines for evaluating the effectiveness of investments. Trans. from English. Revised. and supplemented. ed. - M .: JSC "Interekspert", "INFRA-M", 528.

Gukova, A.V, Egorov, A. J. (2006). The investment capital of the enterprise. M .: "KnoRus" 276.

Guidelines for evaluating the effectiveness of investment projects (second edition) (2010), approved by the Ministry of Economy, Ministry of Finance and the State Construction Committee of Russia 21.06.1999 N VC 477, 2010 Last Editedr.

Takhautdinov, Sh, Zagirov, M.M, Kvon, G.M (1998) Cost-effectiveness of measures aimed at improving the operational reliability and durability of the oil facilities, Oil Industry. 7, $86-89$.

Galeev, RG, Takhautdinov, Sh, Magalimov, A.F, Zagirov, M.M et al. (1998). The main directions and results of anti-corrosion of oilfield equipment. Oil Industry. 7, 43-45.

Kvon, G.M (2009) Investment project: evaluation of effectiveness: a teaching aid for students studying in the field of "Management", "Finance and Credit" in the field of Economics and Management (teaching aid). Kazan: Publishing house "Poligran-T", 108.

Kvon, G.M, Zagirova, F.Sh. (2005), "Economic aspects of the efficiency of the creation and use of competitive products" (monograph) . Kazan: "Taglimat" IEUP, 80.

Kiseleva, O.V., Makeeva, F.S. (2013). Investment analysis: a tutorial. Grief UMO.-M .: in KNORUS, 200.

Lakhmetkina, NI (2012) The investment strategy of the enterprise: Manual, 6th izd.-M .: in KNORUS, 232.

Lipsitz, I.V., Kossov, V.V (2011)/ Investment Analysis. Preparation and evaluation of investments in real assets. M.: INFRA-M, 320.

Kondratyev, V.B., Kurenkov, Y., Varnavskiy, V.G. (2005) Features of the investment model of Russian Institute of World Economy and International Relations RAN.-Nauka, 309.

Teplova, T.V Investment leverage maximize the value of the company. The practice of Russian enterprises (2009). -M.: Top, 272.

Khasanova, A.Sh., Kvon, G.M. (2014) Analysis of investment management system in the region (on the example of the Republic of Tatarstan) (monograph) .- Kazan LLC "RPK" Omega ", 116.

Khamidullin, FF, Kwon, GM (2012) Risk assessment of investment projects in the housing and communal services: quantitative aspect. Problems of Modern Economics, 1 (41), 318-322.

Yakupova, N.M, Yarullina, G.R (2010). Investment Attractiveness: analysis, measurement and evaluation. -Kazan: Kasan. gos.un t,176. 